\title{
Polar bear predation on ringed seals in the fast-ice of Hornsund, Svalbard
}

\author{
IAN GJERTZ AND CHRISTIAN LYDERSEN
}

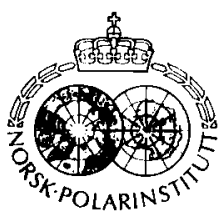

\begin{abstract}
Gjertz, I. \& Lydersen, C. 1986: Polar bear predation on ringed seals in the fast-ice of Hornsund, Svalbard. Polar Research 4 n.s. 65-68.

Polar bear hunting success on ringed seals in subnivean lairs and basking on the fast ice, was studied in Hornsund, Svalbard. A few bears were observed while actually hunting, but in most cases bear tracks were followed by snowmobile to determine the outcome of hunts. Seal carcasses were classified from size and tooth annuli as pups, juvenilcs or adults. A total of 62 subnivean structures were entered by bears, with six seals killed. One of ten charges on basking seals resulted in a kill. Success rates of bears in Hornsund arc compared with results of studies in Canada and Svalbard. $\square$ Hunting success, polar bear, predation, ringed seal
\end{abstract}

Ian Gjertz and Christian Lydersen, Norsk Polarinstitutt, PO Box 158, 1330 Oslo Lufthavn, Norway; July 1985 (revised January 1986).

Ringed seals (Phoca hispida) associate closely with landfast sea ice, in which they maintain breathing holes with the aid of their foreflippers. Frozen into this ice are icebergs, smaller blocks of glacier ice and pressure ridges. When sufficient snow accumulates around these irregularities, the seals may dig haul-out lairs in the snow over their breathing holes (Smith \& Stirling 1975), which then offer protection from predators and cold. In late March and April females give birth to a single pup, usually in a lair.

During winter, polar bears (Ursus maritimus) in the Svalbard archipelago feed almost exclusively on ringed seals (Lønø 1970). During the summer they are less dependent on ringed seals, although these animals continue to constitute their main prey. Polar bears hunt ringed seals on the ice by waiting for them at their breathing hole (still-hunting) and by stalking seals which are hauled out on the ice (Stirling 1974). When hunting ringed seals in lairs, the polar bear pounces on snow in order to break through the roof and get at the seal (Stirling \& McEwan 1975).

The purpose of this study was to assess the success rates, i.e. the number of hunts leading to a kill compared to the total number of hunts, of polar bears hunting ringed seals in a Spitsbergen fjord with emphasis on the hunting of seals in subnivean lairs.

\section{Methods}

Hornsund $\left(77^{\circ} \mathrm{N}, 16^{\circ} \mathrm{E}\right)$, a southern fjord in the Svalbard archipelago, was chosen as study area.
Each spring a large number of polar bears pass through this area on their way to the eastern parts of the archipelago (Larsen 1986).

The fjord ice was searched by snowmobile for polar bear tracks, which were followed to determine if the bear had been hunting. Tracking with snowmobiles could disturb still-hunting polar bears. In addition, it is difficult from tracks to distinguish between still-hunting and resting. Consequently it was decided to concentrate on bears hunting seals in lairs and stalking at breathing holes, but to record any kills done by stillhunting.

In cases where bears had been stalking ringed seals hauled up at their breathing holes, the distance from the spot where the bear started the charge to the hole was measured. Tracks leading past seal holes showing no such change of pace were disregarded. Ringed seal lairs attacked by polar bears were classified as either haul-out lairs or, when traces of a ringed seal birth were present, as a birth lair. Such traces included remains of placenta, whitecoat hairs or tunnelling in the lair by the pup (Smith \& Hammill 1981).

In cases where hunting had been successful, seal remains were examined to determine the sex. Seals were classified as pups, juveniles or adults from examination of size and tooth annuli.

\section{Results}

A total of 31 bears were counted in the study area between 5 and 28 April. With the exception of a female with two two-year-old cubs, no bears 
Table 1 . Success rates of polar bears hunting seals at lairs and snow-covered breathing holes.

\begin{tabular}{lllr}
\hline Site & Attempts & \multicolumn{1}{c}{ Kill } & $\%$ success \\
\hline Haul-out lairs & 37 & 1 adult & 2.7 \\
Birth lairs & 12 & 4 pups & 33.3 \\
Breathing holes & 13 & 1 juvenile & 7.7 \\
Total & 62 & 6 & 9.7 \\
\hline
\end{tabular}

remained for very long in the area. The majority of bears appeared to be wandering in an eastward direction.

Forty-nine bear attacks on seal lairs were recorded. Of these, twelve were classified as birth lairs. In addition, thirteen snow-covered breathing holes had been attacked. Table 1 lists lairs attacked, and gives success rates of polar bears hunting seals at lairs and snow-covered breathing holes.

In only ten cases did stalking of seals across the fjord fast-ice end in a charge. The length of the charge varied from $15 \mathrm{~m}$ to $80 \mathrm{~m}$ and was on average $41 \mathrm{~m}$. One of the ten charges was successful resulting in the killing of an adult ringed seal of unknown sex.

On two occasions still-hunting bears were found to have been successful. Both of the seals killed were juveniles. Only one could be sexed and was a female.

\section{Discussion}

The ice situation in Hornsund in the spring of 1985 was unusual; the fjord froze at the end of March, some two months delayed. Few areas of pressure ridges or ice hummocks were present. This made most of the fjord unsuitable for ringed seal lairs, resulting in cases of ringed seals being born on open ice, which is unusual in this area of Spitsbergen (Gjertz \& Lydersen 1983). Only two suitable areas for lairs, both measuring approximately $2.5 \times 0.5 \mathrm{~km}$ were found (Fig. 1). Polar bears had thoroughly searched both of them for lairs.

Because of the steady passage of bears through Hornsund and the limited area for ringed seal haul-out lairs, most of the seals in the hummock ice areas had been disturbed by bears and had probably moved to other areas. Seals hauled-out on open ice were as a rule observed going into the water from several hundred metres distance when approached by a possible predator, which may explain the low number of polar bear stalks ending in a charge. In this study lengths of charges varied from $15 \mathrm{~m}$ to $80 \mathrm{~m}$, on average $41 \mathrm{~m}$. This is somewhat longer than the $15-30 \mathrm{~m}$ of Stirling (1974). However, Stirling estimated the length of the charge from a distance through a telescope, while in this study it was actually measured from tracks. Stirling's observations were done in midsummer when ringed seals according to our experience are more easily approached than they are in the early spring. Smith (1980) noted one successful polar bear charge of an estimated $80 \mathrm{~m}$ in late spring in Canada.

Stirling (1974) states that stalking on the fast ice is an inefficient means of hunting, which seems to agree with the observations from the Hornsund area. Only one of the ten charges was successful. Bears or their tracks were often observed to be moving in the direction of basking seals, but rarely got close enough to result in a charge before the seals dove. According to Stirling (1974), stillhunting is a more effective means of hunting than stalking, and most hunting by polar bears during the summer is done by this method (Stirling \& McEwan 1975). While this study was not concentrated on still-hunting, it was still twice observed to have been successful.

Information from previous studies on polar bear predation on seals in subnivean structures in Canada are given by Smith (1980) and Stirling \& Archibald (1977), and for Svalbard by Taugbøl (1982) and Lydersen \& Gjertz (1984). A comparison of polar bear hunting success rates is given in Table 2.

As shown in Table 2, the polar bear hunting success rates on subnivean structures found by Stirling \& Archibald (1977) and Lydersen \& Gjertz (1984), correspond with those found by us in Hornsund, while Smith (1980) found these rates much higher than those from Hornsund. Taugb $\emptyset 1$ (1982) found a total of 170 subnivean structures depredated, but only gives success rates for attempts on birth lairs. This study is therefore not fully comparable with the others in Table 2.

Since polar bears rarely eat the whole seal it may be possible to age and sex seals from the remains of the carcass. On land, carcasses are often scavanged by birds and arctic foxes (Alopex lagopus) (Stirling \& Archibald 1977), leaving little to facilitate sexing and ageing. In the fjords of Spitsbergen foxes are common, and tracks of foxes were almost always found next to seal 


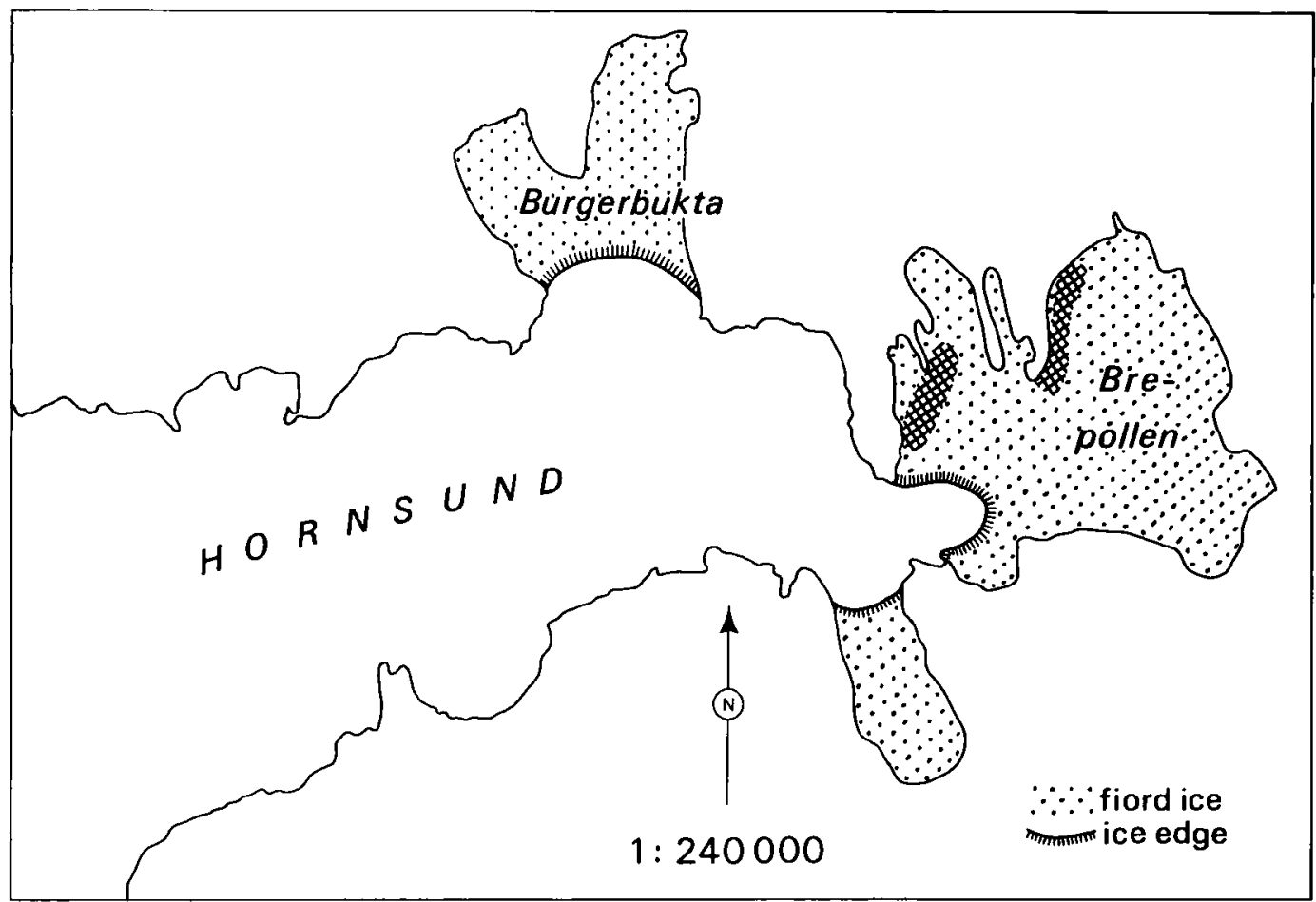

Fig. 1. Hornsund, Svalbard.

remains. Ivory gulls (Pagophila eburnea) and glaucous gulls (Larus hyperboreus) are the important avian scavengers on seal carcasses in Spitsbergen. In Hornsund 45 glaucous gulls were observed next to the carcass of a bearded seal
(Erignatus barbatus). Of the nine seal carcasses found in Hornsund (4 whitecoat) only one could be sexed. The bear was observed catching and eating the seal in question and the remains were checked before scavanging started. Of the nine

Table 2. Comparison of success rates from different studies of polar bears hunting seals at subnivean structures.

\begin{tabular}{llll}
\hline Study/site/year & Attempts & Successes & \% success \\
\hline Smith 1980: & & & \\
Western Canadian Arctic & 5 & 1 & 20 \\
1972-75 & 110 & 21 & 19.1 \\
Central and Eastern High Arctic 1975-76 & 47 & 15 & 31.9 \\
Southeastern Baffin Island 1978-79 & & & 8.6 \\
Stirling \& Archibald 1977: & 556 & 48 & 6.7 \\
Western Arctic 1971-73 & 120 & 8 & 6.4 \\
$\quad$ 1974-75 & 172 & 11 & 36.8 \\
Eastern High Arctic 1972-75 & & & 7 \\
Taugbøl 1982*: & 19 & & 7.7 \\
Kongsfjorden, Svalbard 1979-80 & & 1 & 9.7 \\
Lydersen \& Gjertz 1984: & 13 & 6 & \\
Kongsfjorden, Svalbard 1984 & 62 & & \\
Present study: & & & \\
\hline
\end{tabular}

\footnotetext{
* = figures for predation on birth lairs only.
} 
seals found killed in this study, seven were young (three juveniles and four pups). This is in agreement with Smith (1980). Stirling \& Archibald (1977) similarly found that pups and subadults constituted the larger part of the seals killed, and postulated that under normal circumstances pups and subadults form the largest proportion of the kill because they are less experienced and consequently more easily caught. They may also be situated in areas more vulnerable to predation.

\section{Conclusion}

Hornsund seems to be a well suited area for surveying polar bear hunting success. The extraordinary ice conditions experienced in Hornsund during the study period necessitate further field work to enable a more accurate assessment of polar bear hunting success.

A comparison of polar bear hunting success in Canada and Svalbard is difficult. mainly because more material is needed from Svalbard. Factors such as differences in ice and snow conditions, climate, distribution of birth lairs, and dates of studies are also of significance when comparing results from these areas.

Acknowledgements, - We thank the Norwegian Polar Research Institute for funding this project, and the crew of the Polish Polar Station in Hornsund for the use of their facilities and all help rendered us. We also thank the Sysselmann (The Governor of Svalbard) for his assistance. Drs. Åge Jonsgård and Dave Griffiths commented on the manuscript.

\section{References}

Gjertz. 1. \& Lydersen C. 1983: Ungekasting hos ringsel i Svalbard-området. Fauna 36, 65-66.

Larsen. T. 1984: Population biology of the polar bear in the Svalbard area. Norsk Polarinst. Skr. 184.

Lydersen. C. \& Gjertz. I. 1984: Studies of the ringed seal (Phoca hispida Schreber 1775) in its brecding habitat in Kongsfjorden, Svalbard, Norsk Polarinstitutt Rapportserie Nr. 19. 46 pp.

Lonø, O. 1970: The polar bear (Ursus maritimus Phipps) in the Svalbard area. Norsk Polarinst. Skr. 149. 103 pp.

Smith. T. G. 1980: Polar bear predation of ringed and bearded scals in the land-fast sea ice habitat. Can. J. Zool. 58, 22012209.

Smith. T. G. \& Hammill, M. O. 1981: Ecology of the ringed seal, Phoca hispida, in its fast ice brecding habitat. Can. J. Zool. 59. 966-981

Smith. T. G. \& Stirling, 1. 1975: The breeding habitat of the ringed seal (Phoca hispida). The birth lair and associated structures. Can. J. Zool. 53, 1297-1305.

Stirling. I. 1974: Midsummer observations on the behavior of wild polar bears (Ursus maritimus). Can. J. Zool. 52, 11911198.

Stirling. I. \& Archibald. W. R. 1977: Aspects of predation of seals by polar bears. J. Fish. Res. Bd. Can. 34. 1126-1129.

Stirling. I. \& McEwan. E. H. 1975: The caloric value of whole ringed seals ( $P$ hoca hispida) in relation to polar bear (Ursus maritimus) ecology and hunting bchavior. Can. J. Zool. 53, 1021-1027.

Taugbøl. G. 1982: Thermoregulation, energy balance and development of ringed seal pups in their first weeks of life. Cand. real. thesis. Zoofysiol. Inst. Univ, Oslo. $102 \mathrm{pp}$. (in Norwegian). 